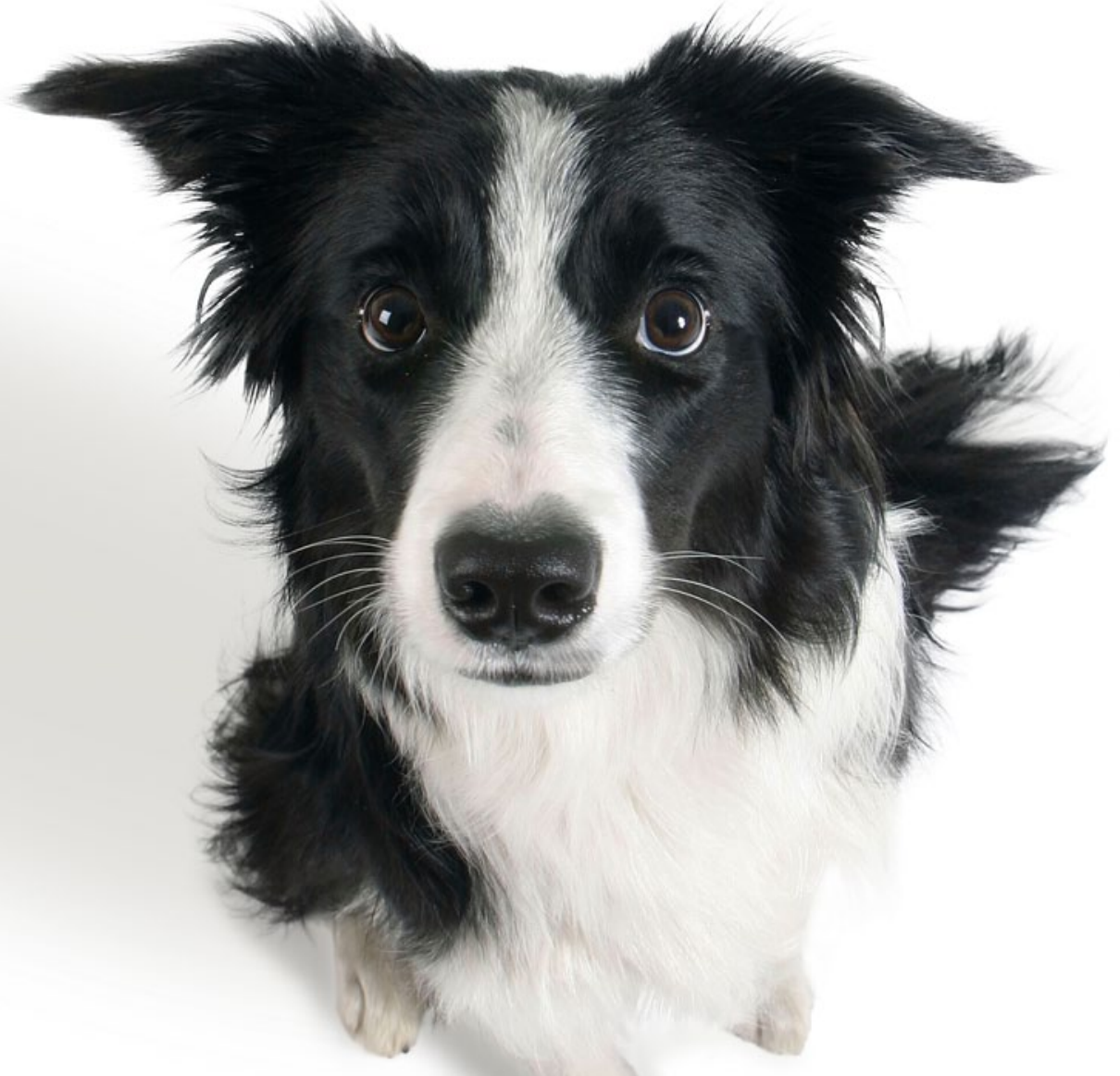

ボーダー・コリーは不安障害の 遺伝学の解明に役立ってくれる だろうか。

\title{
いつでも犬は最良のパートナー
}

\section{Pet project}

\section{DAVID CYRANOSKI 2010 年 8 月 26 日号 Vol. 466 (1036-1038)}

犬は、旧石器時代から飼われている我々の古くからの友だちである。

最近、ヒト神経精神疾患に関与する遺伝子スクリーニングが目的で、

イヌに注目が集まっている。人間は犬と新しい相互関係を作るのだろうか。

11 歳になるボーダー・コリーの Solo は、 抗うつ㶡のフルオキセチンやアミトリ プチリンを年中投与されている。その うえ、毎年、米国独立記念日の打祭り 騷ぎの間、神経をなだめるためにザナッ クス（アルプラゾラム）をいつもの 2 倍投与される。雷鳴や発砲音といったた
いがいの種類の爆発音で神経が高ぶり、 イライラしたり怯えたりしてしまうた め、独立記念日のお祝いの花火はかなり 危険なのだ。爆発音を聞くと、彼は八 アハアと息を荒くしてょだれを垂らし、 目を大きく見開いて、必死に隠れ場所 を探す。もし近くにほかの犬がいれば、
攻撃しかねない。「そうした行動は、不 安の置き換えとよばれます」と、Solo の飼い主、オレゴン大学 (米国ユージー ン）の進化生物学者の Melanie Chang は話す。

Chang は、カリフォルニア大学サン フランシスコ校（米国）でポスドクだっ たころ、雑音恐怖症の原因遺伝子を調べ るプロジェクトの一環として、ボーダー。 コリーの DNA サンプルを数百個集める 作業にかかわり、Solo の試料も採取し た。Chang の推測では、ボーダー・コ リーの少なくとも50\%が雑音恐怖症で あり、うち $10 \%$ は重症で、場合によっ ては大きな雑音に反応して自分やほかの イヌを傷つける可能性があるという。力 リフォルニア大学サンフランシスコ校の 精神科医で、このプロジェクトの主催者 Steven Hamilton は、コリーのパニッ クとヒトの不安障害の間には類似点がみ られ、「容易に類似点が見つかります」 と話す。また、同じ薬剤が、ヒトとイヌ の症状に対してほぼ同じ比率で効く。現 在、このような、精神疾患に悩まされる イヌを助け、なおかつヒトの神経精神疾 患の原因を解き明かそうという研究プロ ジェクトの数は増えつつある。

ヒトで精神医学上の問題を引き起こす 遺伝子の探索は、「努力の割には成果が 挙がっていません」と、ウェルカムトラ スト・ヒト遺伝学センター (英国オック スフォード）の Jonathan Flint は話す。 その原因の一部は、ヒトゲノムが複雑で あることと、この種の疾患に対して常に 一貫した診断を下すのが難しいことにあ る。しかし、200 年にわたる選択的な同 系交配のせいで、イヌは犬種に特異的な 一群の行動を取るようになり、また、イ ヌのゲノムはそうした行動の原因遺伝子 を比較的追跡しやすくなっている。「イ ヌは、唯一、生まれながらの精神疾患モ デルです。遺伝子地図の作製や遺伝子ク ローニングに関しても、完璧で申し分の ない動物です」と、マサチューセッッ工 科大学 (米国ケンブリッジ) のマウス遺 伝学者 Guoping Feng は話す。彼は現在、 
イヌの研究者との共同研究を立ち上げよ うとしている。

ボーダー・コリーは、放牧した家畜を 集めたり、遠くからの主人の呼び声を聞 き取ったりできるよう品種改良された。 このため聴覚が鋭くなりすぎ、一部は大 きな雑音に耐えられず、ヒトの不安障害 に似た状態に陥るのではないかという 見方もある。「一般的にイ又に不安障害 の症状が多いのは、ヒトの社会的指示に 応答できるよう、長期にわたる選択がか かったせいでしょう」と Chang はいう。 その他の形質の起源はよくわかっていな い。例えば、ドーベルマン・ピンシャー は忠実な番犬として品種改良されたが、 ヒトの強迫行為に似た病的な固執や奇行 を示すことも多い。またダルメシアンは、 おそらくウマと並走できるようにスピー ドと持久力をもつよう品種改良され、攻 撃的な傾向がある。

イヌにみられる特定の気質が偶然の産 物なのか、それとも特定の性質を求めた 選択による不測の結果なのかは、推測 の域を出ない。しかし、行動障害は間 違いなく高頻度でみられる。動物行動 の専門家であるタフッ大学 (米国マサ チューセッッ州ノースグラフトン）の Nicholas Dodman は、米国で飼わ秃て いる 7750 万匹のイヌのうち、最低でも 40\%は何らかの行動障害をもっている と見積もっている。現在、ペット用の向 精神薬などの薬剤は好調な市場の 1 つ である。また残念なことに、こうした問 題を抱えるイヌの多くは、そうした気質 ゆえに安楽死させられている。

研究者たちが、ヒトよりもイヌのほう が遺伝上の謎を明らかにしやすいだろう と考えるのには、ちゃんと理由がある。 例えば今年の研究で、イヌの体の大きさ にみられる多様性の $80 \%$ 、か、イヌゲノ 厶内の 6 か所にある変異によって説明 できることが示された ${ }^{1}$ 。対照的に、今 年発表されたヒトの研究では、身長に関 する一般的な変異は、29 万 4831 か所 あるが、それでも身長差の $45 \%$ しか説 明できないという。
しかし、身長の遺伝学がイヌとヒトで それほど違うなら、果たして、不安障害 や強迫行為、攻撃性といった症状の遺伝 学的特性が両者で似ていると考えていい ものか、という疑問が出てくる。ノース カロライナ大学（米国チャペルヒル）の 遺伝学者 Patrick Sullivan は、「ヒトと ほかの動物種で興味深い類似性があるよ うにみえる行動でも、遺伝学的には完全 に異なる機構になっている可能性があり ます」と話す。これは、同じ形質でも、 異なる遺伝子や脳の異なる器質に由来す ることを意味する。しかし、イヌの研究 の支持者たちは、イヌの遺伝子がヒト疾 患を解明する手がかりになるだろうし、 また十分ではないかと考えている。

\section{眠れる犬を起こす}

イヌを用いた研究でヒト疾患に関する 「答え」が得られることは、少なくとも 1 つの成功例から明らかである。強い眠 気の発作を起こすヒトの睡眠障害、ナル コレプシーの原因遺伝子を見つけ出すた め、研究者たちは過去数十年にわたって 患者の DNA をひたすらろるいにかけて きた。しかし、関与する遺伝子は多いう えに、環境要因に整合性がなく、はっき りした仕組みは何もわからなかった。ナ ルコプレシーが自己免疫疾患かどうかと いう議論はありましたが、どう研究した らよいか誰もわかりませんでした。とに かく難しすぎたのです」と、スタンフォー ド大学医学系大学院（米国カリフォルニ ア州レッドウッドシティ）で睡眠を研究 し、分子薬理学にも詳しい Emmanuel Mignot は話す。

しかし、ドーベルマン・ピンシャー はナルコプレシーを高頻度で発症しや すく、この研究を進めるカギになった。 1989 年、Mignot は古典的な遺伝学技 術を用いてナルコプレシーのドーベルマ ンを作り出し、この疾患の遺伝パターン を追跡することを始めた。現在のような 便利な遺伝学やゲノム解析のッール類は なく、1つの遺伝子にある変異が病因と なることを突き止めるまでに 10 年を要
した。それは、オレキシンとしても知ら れる神経伝達物質ヒポクレチンの脳内取 り込みを調節する、ヒポクレチン受容体 2 の遺伝子だった ${ }^{2}$ 。

Mignot は、ヒトの相当遺伝子に同じ 変異を見つけ出せなかったが、ヒポクレ チン経路の変異を見つけた ${ }^{4}$ 。そこで 我々は脳脊髄液のヒポクレチン量を測定 し始めました。すると、ナルコプレシー 患者にはヒポクレチンが認められません でした。それは特筆すべきことでした」 と Mignot は話す。現在、研究の焦点は ヒポクレチン減少やナルコプレシーに結 びつくヒト遺伝子の変異に移ってきてお $り^{5}$ 、製薬企業が不眠症治療薬の探索の 足がかりになりそうなヒポクレチンに狙 いをつけている。

\section{新しい技術で挑む}

Mignot がナルコプレシーに関する研究 を発表してからしばらく経って、イヌ のゲノムが解読された ${ }^{6}$ 。そのおかげで やっと、一塩基多型（SNP）を利用して 何百匹ものイヌのゲノムを迅速かつ容易 に比較できるようになった。SNP は集 団内に一定以上の頻度でゲノムにみられ

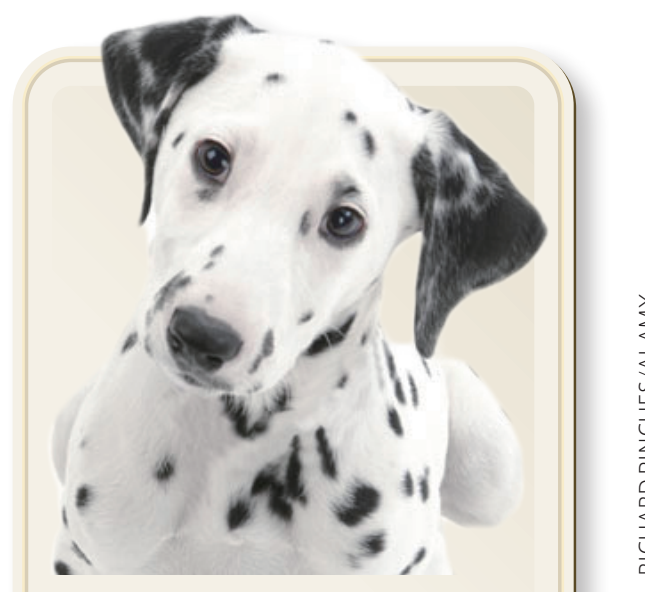

ダルメシアン

品種改良：

1790 年代に確立され、馬車といっしょ に走る馬車犬として広く用いられた。

障害 :

難聴になりやすく、また、尿路結石に つながる高尿酸血症になることもある。 攻撃的な傾向がみられる。 
る塩基 1 個の変異で、遺伝する DNA ブ ロックごとのマーカーとなる。

こうしたマーカーを使って行われる全 ゲノム関連解析 (GWAS) は、ヒトより もイヌのほうがずっと簡単である。大半 の犬種は極度に均質で、同じ犬種のイヌ どうしが共有する DNA ブロックは、ヒ ト 2 人が共有する DNA ブロックよりも かなり大きい。それはつまり、イヌで疾 患と確実に関連するDNA ブロックを見 つけ出すには、ヒトよりも少ない SNP と 少ない個体数を調べればすむということ だ ${ }^{7}$ 。ブロード研究所（米国マサチュー セッッ州ケンブリッジ）の Kerstin Lindblad-Toh によれば、ヒトの GWAS の場合、研究対象の形質とゲノム内の特 定領域とに十分な関連性があることを示 すには、その形質をもつ人ともたない人 （対照）が、それぞれ 5000 人ずつ必要 になるだろうという。しかしイヌの場合 はもつと少なく、その形質をもつ 100 匹 と対照個体 100 匹ですんでしまう。また、 ヒトでは数十万か所の SNP を調べるこ とが必要な研究でも、イヌではわずか 1 万 5000 か所ですむことがある。

イヌの GWAS は、ヒト疾患と関連す るいくつかのイヌ形質の遺伝子発見に成 功を扮さめている。例えば、骨形成不全 症はダックスフントのずんぐりした足の 原因遺伝子と関連付けられており ${ }^{8}$ 、自 己免疫疾患である全身性エリテマトーデ スは、今年発表の研究で、ノヴァ・スコ シア・ダック・トーリング・レトリーバー の 5 種類の遺伝子と関連することが明 らかになっている ${ }^{9}$ 。そして今後も成果 は増えていくだろう。リエージュ大学(ベ ルギー）の獣医 Anne-Sophie Lequarré は、イヌ遺伝学研究を先導するヨーロッ パのプロジェクト「LUPA」のまとめ役 を務めている。2008 年に 1200 万ユー ロ（約 14 億円）の予算で始動したこの プロジェクトは、拉々そ 100 人の研究 者を結集して、1 万匹のイヌの遺伝子型 を解析し、単一遺伝子疾患や複合要因 疾患（がん、心血管疾患、神経障害な ぞ）を調べょうとしている。LUPA に参

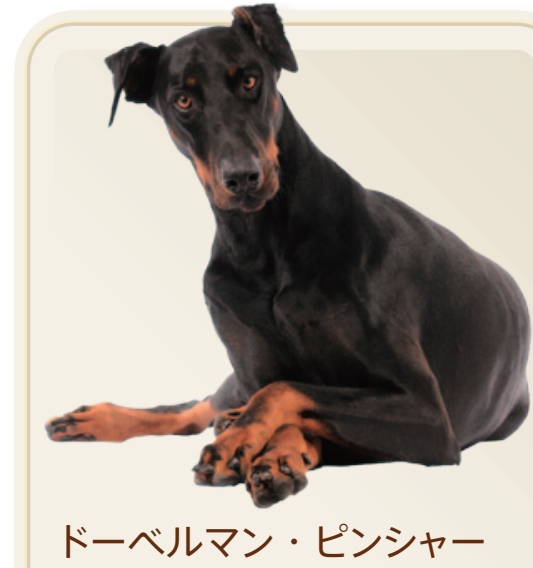

品種改良：

1890 年ごろにドイツ・チューリンゲン のKarl Friedrich Louis Dobermann により、番犬として最初に品種改良さ れた。

\section{障害 :}

ナルコプレシー、イヌ強迫性障害、頸椎 不安定症、および凝血障害のフォン・ヴィ レブランド病を発症する場合がある。

加している研究者たちはまもなく、ヒト 疾患に相当するイヌ疾患の原因遺伝子で

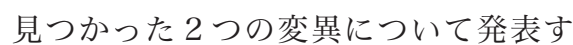
る予定だと、Lequarré は話す。「最初に 得られた結果から、イヌである遺伝子に 疾患と関連する変異が見つかつた場合に は、ヒトでもそれと同じ遺伝子が症例の $90 \%$ に関連することが実際にわかって います」。

強迫性障害 (OCD) は、イヌの研究 によりヒトの行動病態が解明される最初 の疾患になるかもしれない。ヒトの強迫 性障害に関連するとみられるマウスの遺 伝子については、60 以上の研究がある が、これまでのところ再現性のある十分 な関連性を見いだせていない ${ }^{10}$ 。しかし、 強迫行為がみられるイヌは多数存在す る。例えばブル・テリアは、自分の尻尾 をしつこく追いかける「尾追い行動」を とるものが多い。ドーベルマンやジャー マン・シェパード、グレート・デーン、ゴー ルデン・レトリーバーなどの多くの大型 犬種は、毛がなくなるまで自分の脇腹を かじったり足をなめたりして皮膚を傷つ けてしまい、場合によっては足の機能ま で損なうこともある。これは、OCD 患
者の、異常なまでの手洗い行為、何度も 物事を確認する行為、ある特定のやり方 でやらないと気がすまない行為などの強 迫症状にいくぶん匹敵する習性である。

今年 1 月に Lindblad-Toh と Dodman は、イヌの強迫性障害とイヌ第 7 染色 体上の領域の間に関連性があることを 報告した ${ }^{11}$ 。この研究は、強迫的な䟧 み癖のあるドーベルマン 90 匹余りと約 70 匹の対照群のゲノムで、1 万 4700 か所の SNP を解析した結果に基づいた ものだ。この強迫行為は、40 万塩基の 長さの DNA 内にある変異と関連付けら れた。行動リスクに関与するこの変異と 強迫行為の間の結びつきは完全なもので はないが、それでも十分である。この変 異は、自分の脇腹や毛布、その他噛める ものは何でも噛むドーベルマンの $60 \%$ に認められたが、もつと軽度な噛み癖の ドーベルマンでは 43\%、強迫行為が全

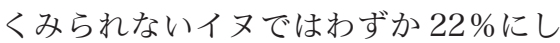
かなかった。

Lindblad-Toh と Dodman が狙いを つけた領域内にある 1 つ遺伝子には、 既にほかの研究者も注目している。その 遺伝子とは、神経細胞間の接着を形成す るタンパク質カドヘリン 2 をコードす る $\mathrm{CDH} 2$ だ。マウント・サイナイ医科 大学 (米国ニューヨーク州) の神経科学 者 Deanna Benson は、ほかの研究者も カドヘリンが OCD に関与している可能 性に興味を抱いているだろう、と話す。

OCD のマウスモデルを作っている Feng も、OCD とカドヘリンの関連性を 探しているところだ。Feng と LindbladToh は今秋、マウス、イヌ、ヒトに共通 の強迫症状に関係する脳内回路を見つけ るための共同研究を開始した。Feng は 現在、マウスの特異的な脳領域で $C d h 2$ をノックアウトして機能を消失させ、 OCD に似た行動が生じるかどうかを調 べている。

\section{犬のごとく辛抱強く}

Lindblad-Toh は現在、ヒト OCDに遺 伝学的にもっとぴったり当てはまる例を 
探しているところだ。イヌの遺伝学研究 は 2 段階で進められる。まず、1 つの犬 種内で、対象を 1 つの大きな DNA 領域 までしぼり込み、次に、同じ障害をもつ ほかの犬種の DNA で、同じ領域内の重 なる箇所を探すのである。Mignotは、 彼の居眠りばかりするドーベルマンで発 現している変異に狙いを定めるのに、ナ ルコプレシーのダックスフントを利用し た。また Lindblad-Toh は、脇腹をしゃ ぶる癖のあるジャーマン・シェパードや 尾追い行動をするブル・テリアで DNA ブロックを比較することで、第 7 染色 体上にある 40 万塩基もある関連領域を、 もっと研究しやすい 1 万塩基までしぼ り込みたいと考えている。Hamiltonも、 雑音恐怖症の研究対象を、ボーダー・コ リーから、同様の不安障害を示すビア デッド・コリーやオーストラリアン・シェ パードまで広げようとしている。

しかしイヌの遺伝学研究にも、ヒト 疾患研究と同様な問題がいくつかあっ て、なかなか難しい。まず、神経精神疾 患の診断がそもそも当てにならない。例 えば統合失調症は、それぞれ異なる遺伝 的・環境的な要因で発生するさまざまな 疾患の寄せ集めである可能性がある。ま た、被験者を症状で分類しても、その基 盤となる疾患が異なっている場合には、 GWAS によって混乱をまねくような結 果が出る可能性がある。「ほんの数匹の イヌのせいで解析対象集団が役立たなく なることもあります」と Lequarré はい う。彼女は、重要な関連性を何も引き出 せなかったあるてんかん研究を引き合い に出した。その研究チームは、後に、疾 患集団のイヌの一部が実際には、研究対 象とは違う型の遅発性てんかんだったこ とを知った。「表現型の決定は非常に重 要です。確実に同じ疾患をもつイヌを集 める必要があるのです」と彼女はいう。

LUPA では今、診断を明確化しょうと 尽力しており、神経疾患の診断名を首尾 一貫させるために、標準的なイ又気質解 析手順に従う獣医を選定した。標準化は 正しい解決法だと Hamilton はいう。彼
のコリーに関する研究では、24ページ にわたる質問表で飼い主から客観的所見 を引き出している。「『あなたの犬は攻撃 的ですか？』という質問はいけません。 『激しい雷雨に出会ったとき、あなたの 犬はどうしますか？』と質問するので す」。LUPAの神経疾患部門は、イング リッシュ・コッカー・スパニエルとイン グリッシュ・スプリンガー・スパニエル にみられる攻撃性に注目している。両犬 種とも、突然激しく怒り出す性質がある。 研究チームは、こうした研究によって、 ヒトの双極性障害（躁うつ病）や統合失 調症、その他の攻撃性を含む精神障害に 関連する遺伝子変異を突き止められると 期待している。

イヌモデルの人気は広まりつつある。 東京大学の獣医動物行動学研究室に所 属する武芮ゆかりは、200匹の柴犬と 200 匹のラブラドール・レトリーバー から DNA 試料を収集し、柴犬では攻撃 性、レトリーバーでは集中力欠如の基盤 にある遺伝子を探し出した。この成果は、 ある現実的な問題の解決に役立つだろう と、彼女は話す。注意散漫なレトリーバー

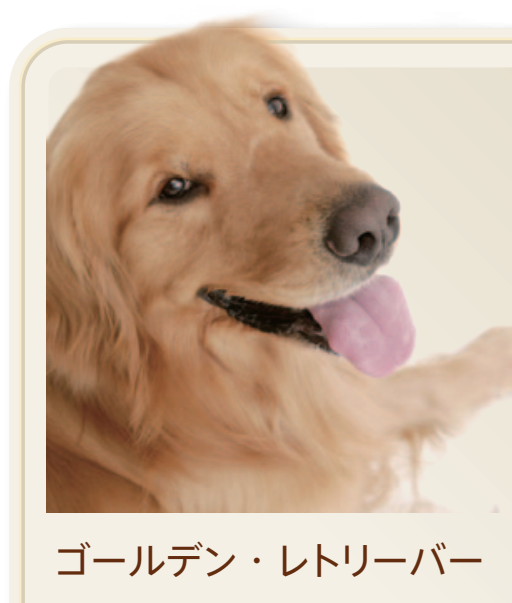

品種改良 :

1800 年代半ばに、遠く離れた場所か ら銃で撃った水鳥を探し出して回収す るために品種改良された。

\section{障害 :}

友好的、温和な気質でよく知られている が、なかに、、攻撃的で支配的なものも いる。てんかん、およびある種の強迫性 障害の傾向がみられる。
は、よい盲導犬になれない。ブリーダー は、その原因となる遺伝子変異を知るこ とで、盲導犬に適さない犬を繁殖させず にすむだろう ${ }^{12}$ 。

イヌを使った研究が期待どおりにヒト の精神疾患の解明や治療につながって も、あるいはそうでなくても、犬には きっと恩恵がもたらされることだろう。 ブリーダーたちは既に、特定の犬種に障 害をもたらすいくつかの遺伝子変異を気 に留めるようになっている。犬の性質や 体質をよりよくするため（科学研究の面 からいえば研究対象がなくなり状況は悪 化するのだが)、スクリーニングやさら に選択的な品種改良によって、次世代の ボーダー・コリーでは拉そらく、研究材 料になる Solo のような不安障害の個体 はほとんど誕生しないだろう。

国立ヒトゲノム研究所（米国メリーラ ンド州ベセスダ) のイヌ遺伝学者 Elaine Ostrander は、犬たちは暖かい毛皮や 湿った冷たい鼻先で癒してくれるだけで なく、人間の健康にもさまざまな奉仕を してくれると確信している。「犬は 1 万 年前からずっと、人間の最良の友人です。 人間が狩猟採集民となったときも、農耕 生活を始めたときも、彼らは人間ととも にいました。そしてこのゲノム科学の時 代になって、犬は疾患遺伝子の同定を助 けることでさらに人間に奉仕し、役立つ てくれているのです」と彼女は語った。

(翻訳：船田晶子)

David Cyranoski は Nature のアジア太平洋地域の 特派員。

1. Boyko, A. R. et al. PLoS Biol. 8, e1000451 (2010).

2. Yang, J. et al. Nature Genet. 42,565-569 (2010).

3. Lin, L. etal. Cell 98, 365-376 (1999).

4. Nishino, S., Ripley, B., Overeem, S., Lammers, G. J.\&Mignot, E. Lancet 355, 39-40 (2000).

5. Hallmayer, J. et al. Nature Genet. 41, 708-711 (2009).

6. Lindblad-Toh, K. et al. Nature 438, 803-819 (2005).

7. Karlsson, E.K. \& Lindblad-Toh, K. Nature Rev. Genet. 9, 713725 (2008).

8. Drögemüller, C. et al. PLoS Genet. 5, e1000579 (2009).

9. Wilbe, M. et al. Nature Genet. 42, 250-254 (2010).

10. Wang, L., Simpson, H.B. \& Dulawa, S.C. Behav. Pharmacol. 20,119-133 (2009).

11. Dodman, N. H. et al. Mol. Psychiatr. 15, 8-10 (2010).

12. Takeuchi, Y. et al. Animal Genet. 40, 217-224 (2009). 